(6) OPEN ACCESS

\title{
Doctors in space (ships): biomedical uncertainties and medical authority in imagined futures
}

\author{
Lesley Henderson, ${ }^{1}$ Simon Carter $^{2}$
}

${ }^{1}$ Institute of Environment, Health and Societies, Brunel University London, Uxbridge UK

2Department of Sociology, The Open University, Milton Keynes, UK

\section{Correspondence to}

Dr Lesley Henderson, Institute of Environment, Health and Societies, Brunel University London, Marie Jahoda Building, Uxbridge UB8 3PH, UK; lesley.henderson@brunel. ac.uk

Accepted 31 August 2016 Published Online First 30 September 2016

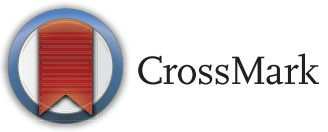

To cite: Henderson $L$, Carter S. Med Humanit 2016;42:277-282.

\section{ABSTRACT}

There has been considerable interest in images of medicine in popular science fiction and in representations of doctors in television fiction. Surprisingly little attention has been paid to doctors administering space medicine in science fiction. This article redresses this gap. We analyse the evolving figure of 'the doctor' in different popular science fiction television series. Building upon debates within Medical Sociology, Cultural Studies and Media Studies we argue that the figure of 'the doctor' is discursively deployed to act as the moral compass at the centre of the programme narrative. Our analysis highlights that the qualities, norms and ethics represented by doctors in space (ships) are intertwined with issues of gender equality, speciesism and posthuman ethics. We explore the signifying practices and political articulations that are played out through these cultural imaginaries. For example, the ways in which 'the simple country doctor' is deployed to help establish hegemonic formations concerning potentially destabilising technoscientific futures involving alternative sexualities, or military dystopia. Doctors mostly function to provide the ethical point of narrative stability within a world in flux, referencing a nostalgia for the traditional, attentive, humanistic family physician. The science fiction doctor facilitates the personalisation of technological change and thus becomes a useful conduit through which societal fears and anxieties concerning medicine, bioethics and morality in a 'post 9/11' world can be expressed and explored.

\section{INTRODUCTION}

In his inaugural speech Dr Robert Wah, President of the American Medical Association (AMA), named Star Trek's iconic physician Leonard 'Bones' $\mathrm{McCoy}$ as his favourite fictional character. In his view, McCoy embodied the qualities of an exceptional leader. He was willing to collaborate to solve problems and to question decisions from a scientific perspective while acting as an advocate for health. Wah explained that "Bones bridged the gaps between the extremes of logic and instinct, rules and regulation, scientific knowledge and human compassion". ${ }^{1}$

There has been considerable interest in how doctors are represented in fictional television ${ }^{2-4}$ and significant research concerning how medicine and medical devices are used in science fiction futures, ${ }^{5-7}$ yet little research to date examines doctors administering space medicine in science fiction. ${ }^{i}$ This is surprising as cultural images of medical professionals have long been considered vital to sustaining the power of institutional medicine. ${ }^{8}$ Furthermore, the science fiction genre offers important spaces for valuable debates concerning medicine, technoscience and the ethical implications or social uses of biomedicine. We argue that the 'space doctor' personalises societal fears and anxieties concerning diverse social issues, including gender and diversity, ethics of surveillance and authority as well as medical enhancement and posthuman futures. Drawing on debates within Medical Sociology and Cultural Studies this article explores how the qualities, norms and ethics represented by doctors in space (ships) are intertwined with issues of gender equality, speciesism and posthuman ethics. Analysis of fictional media stories here starts from the principle that the production of meaning or signification within the narrative is itself a specific practice rather than a mere reflection of reality. The focus of analysis is on the way that narrative discourses become a field in which political and cultural articulations are played out in an attempt to establish hegemonic formations. ${ }^{9}$

Medical drama continues to occupy an extraordinary position in contemporary television with early series such as Dr Finlay's Casebook (19621971) and Dr Kildare (1961-1966) establishing the enduring role of the fictional doctor. Around the same time the character of the 'space doctor' became firmly fixed in television science fiction. Indeed, some of science fiction's most memorable characters have been medical doctors, and it could be argued that the character is now an essential ingredient of the genre. But what are the specificities of television science fiction rather than other forms of fictional drama? Perhaps the first, and most obvious, theme of science fiction is claims about futures. All fictional forms exist within an arena of cultural relationships that are historically

\footnotetext{
${ }^{\mathrm{i}}$ For the purposes of sampling we are including only regular and established characters who are referenced in the programme as having the title 'doctor', being medically qualified, and whose primary function is the delivery of healthcare. On these grounds we have excluded Dr Who. Our analysis does not include nurses who appear occasionally in key series (Nurse Chapel ST: TOS). We envisage that the role of nurse tends to be a background character as opposed to central protagonist. This positioning speaks to different power structures and deserves a separate analysis.
} 
specific, but science fiction, in both its utopian and dystopian forms, uses narratives to project visions of the future in order to disrupt the present-to remind us 'that the future was not going to be what respectable people imagined'. ${ }^{10}$ This leads to a second, and related theme, found in science fiction that presumes that these narrative futures are the result of scientific gadgetry and sociotechnical change. Science fiction often seamlessly combines potential scientific or technological innovation with pseudoscience and pseudotechnology. Yet the important issue for analysis is not realism, but rather is a close reading of what the sign 'science' or 'technology' is attempting to constitute in the narrative-in this case, what is the use of medical technoscience trying to signify? The final theme, as argued by Suvin, is the Brechtian idea of 'estrangement' (verfremdungseffekt) that distinguishes science fiction from myth and fantasy. Myth and fantasy often see human relationships as fixed or supernaturally determined, whereas science fiction focuses on the variable future and problematises human relationships to explore where they may lead in the future. As a representation it "estranges... (allowing) us to recognise its subject, but at the same time making it seem unfamiliar'. ${ }^{11}$ In this paper our analysis draws on these themes to argue that the figure of 'the doctor' is discursively deployed to deliver medical care and frequently acts as a moral compass at the centre of the programme narrative-a conduit through which societal anxieties about the futures of health, sociotechnical change, bioethics and medical science can be expressed and explored.

\section{A simple country doctor (in space)}

Star Trek constitutes a self-contained subgenre within science fiction. ${ }^{12}$ The tremendous influence of Star Trek on the science fiction genre coupled with the global reach of the show means that we focus on this particular franchise in detail. ${ }^{\text {ii }}$ The creator of the show Gene Roddenberry was a humanist, and it was originally intended to have a progressive political agenda, using the genre to tackle contemporary social issues in an enlightened way, though this aim was concealed from the networks at the time. ${ }^{13}$ The role of doctor has been a consistent feature throughout all the 'Trek' franchises with each recreation of the physician being distinctive and mirroring key aspects of the position of medicine in the era in which it was created. The first and best known of the regular Trek doctors from 'Star Trek: the Original Series' (ST:TOS 1966-1969) was Leonard "Bones" McCoy, an idealised General Practitioner with a broad skill range, willing to carry out any procedure. While McCoy regularly used advanced medical technology he was also depicted as being uneasy with some aspects of space living and famously had a phobia about using the ship's matter transporters. He was characterised as becoming easily annoyed yet provided a friendly bedside manner. McCoy was frequently the moral centre of the original series and often argued with the unemotional and utilitarian Vulcan Science Officer, Mr Spock.

Early in the series, McCoy describes himself as a 'simple country doctor', undoubtedly a reference to the classic W Eugene Smith photo essay for LIFE magazine, 'Country Doctor' published in $1948 .{ }^{14}$ This influential photo essay helped to

\footnotetext{
ii Star Trek is one of the longest running science fiction series and in 2016 celebrated its 50th anniversary. First broadcast in 1966, the franchise covers 5 television shows, 13 films and various cartoons, novels and fan fiction spin-offs. Star Trek firmly established the central role of the 'space doctor' and almost all dramas set in space since 'Trek' have continued to place the ship's physician at the heart of the narrative and many reflect elements of McCoy.
}

mythologise the idea of the community-based physician. ${ }^{\text {iii }}$ LIFE researched a suitably attractive location and selected an appropriate doctor, Ernest Ceriani, who was chosen partly for his looks and youth. ${ }^{15}$ Smith's study painted an evocative picture of a hardworking, emotionally drained physician firmly embedded with his patients in the rituals of rural community life. Like McCoy, Dr Ceriani is shown carrying out a wide range of activities-making house calls, talking to patients and conducting operations in surgical gowns. He also bore a more than passing physical resemblance to Dr McCoy. Both the LIFE photos and ST:TOS's Dr McCoy can be read politically in different and somewhat opposing ways. At the time of LIFE's publication, there was considerable debate in the USA about the introduction of compulsory health insurance to increase the number of doctors serving local communities. This was vehemently opposed by the AMA, and the political intentions of the photo essay were to provide a strong counterpoint to debates about US national healthcare or 'socialised medicine'. ${ }^{15}$ The pictures contrast Dr Ceriani striding across agricultural fields to make house calls, with him dressed in a surgical gown in a hospital operating theatre. The lone doctor was thus represented as both traditional and modern. This juxtaposition implies that additional physicians, funded by compulsory insurance, were not neededa single community doctor could do it all. Yet politically Smith, a lifelong liberal, was at variance with the magazine's political intentions for the photo essay. The authentic depictions of medical failure and Ceriani's frozen exhausted stare undermine any message that implies America might not require more doctors.

Similarly, the fictional Dr McCoy presents audiences with a figure that is both traditional and modern. He exhibits some distinctly premodern beliefs about natura medica and the natural healing powers of the body while being comfortable with 23rd-century medical technology. The recurring motif here is the way in which McCoy carries out diagnoses. The Star Trek clinic is shown to contain numerous 'gadgets', including the medical tricorder, a non-invasive medical scanner. While McCoy almost always starts his diagnosis by using his tricorder, he is shown throughout ST:TOS using an older and more traditional diagnostic technique-that of palpation, the method of feeling with fingers and hands during a physical examination. For example, in 'The Deadly Years' (ST:TOS) a mysterious malady causes some crew members, including Captain Kirk, to undergo extreme ageing. During an examination, McCoy initially uses the tricorder on Kirk's body but concludes his diagnosis by making physical contact using fingers to manipulate his patient's joints. It is only after this material connection that he finds Kirk is suffering from advanced arthritis. In, 'The Enemy Within' (ST:TOS), the futuristic technology of the 'matter transporter' provides a plot device to explore good and evil in the human mind. A malfunction in the transporter causes Kirk to split into two ('evil Kirk' characterised by hostility, lust and violence and 'good Kirk' who embodies compassion, love and tenderness). When 'good Kirk', expresses revulsion that his evil doppelganger came from within himself it is McCoy who dispenses simple psychological advice about the human condition. He tells a troubled Captain Kirk that 'we all have our darker side. We need it! It's half of what we are. It's not really ugly. It's Human' (ST:TOS: 'The Enemy Within').

\footnotetext{
iiiSee also 'A Fortunate Man: The Story of A Country Doctor' (1997) in which writer John Berger and photographer Jean Mohr capture the life of an English country doctor and the patients he serves.
} 
The role of McCoy in ST:TOS has to be understood in the context of other popular medical drama which emerged during this period. The portrayal of fictional doctors was being established in television series such as Dr Finlay's Casebook (19621971), Dr Kildare, (1961-1966) Ben Casey (1961-1966) and Marcus Welby MD (1969-1976). Story themes emphasised the dedicated doctor willing to move beyond their professional boundaries to help their patients, motivated not by financial reward but by a noble calling. ${ }^{16}$ Each series centred on the medical hero who was concerned with the lives of their patients, sometimes to their own personal detriment. Many received an official 'stamp of approval' from The AMA Advisory Committee or the American Academy of Family Physicians. At this time medicine was becoming more reliant on hightechnology science, which dramatically improved treatment and raised its cost, with severe consequences for patient-doctor relations in the USA:

As physicians' incomes rapidly increased, and the profession fought to preserve traditional fee-for-service medicine, many viewed the profession as avaricious and uninterested in public health. ${ }^{17}$

In other areas of the mass media and academic medical sociology ${ }^{18-21}$ the flaws in the medical establishment were being very clearly illuminated with critical accounts of medical negligence and lawsuits, rising healthcare costs, and patronising doctor-patient relations. Little of this was depicted in medical drama. Television audiences were captivated by these nostalgic cultural representations which embodied the type of doctors they desired rather than ones who bore a resemblance to their actual healthcare professionals. The television doctors were infallible, had endless time to spend with few patients and were not financially motivated.

The more rushed real-life doctors become, the more leisurely the pace of their fictional counterparts. And the same went for money: as American medicine became increasingly profit orientated, with tales of impecunious patients being turned away from casualty, American medical dramas depicted a medical practice where fees were almost never discussed, and patients never rejected because of their inability to pay. ${ }^{22}$

Setting an entire series in space facilitates significant creative freedom regarding representing the positive aspects of medicine where doctors have infinite time to care for patients and are untroubled by concerns about funding or payment. Turow argues that this utopian view of healthcare began a trajectory of medical drama in which audiences assume that healthcare is a limitless resource. ${ }^{4}$ In ST:TOS McCoy never needs to engage with financing problems. His role depicts a future in which futuristic technoscience and gadgetry has a medical role that complements the more traditional and idealistic functions of the physician. McCoy still has time to provide reassuring psychological advice to his patients and carry out physical examinations manually. Also, it is the futuristic technology in ST:TOS that often provides the defamiliarisation effect in the narrative, such as transporters splitting characters into evil and good dyads. McCoy then comes to stabilise and provides a counterpoint to narrative disruption by using time-honoured traditional medical techniques-those of the 'simple country doctor'.

\section{The female physician: empathy, sexualities, gender and bodies}

Themes of estrangement and the problematising of human relationships dominate storylines involving female physicians in science fiction television. These self-confident female characters provide a crucial counterpoint to the first male-dominated medical dramas and to a wider media responsible for 'the symbolic annihilation of women'. ${ }^{23}$ As a strong leading character in British series 'Space 1999' (1975-1977) Dr Helena Russell conforms to the theme of dedicated and independent physician. As with Dr Janet Fraiser, Chief Medical Officer in Stargate SG1 (1997-2007), Dr Russell could overrule the typical hierarchy of the military setting on the basis of medical authority and defended the ideals of medical ethics against the demands of military necessity. Significantly, within Star Trek: The Next Generation (ST:TNG) there is a gender-integrated crew. However, the two lead female characters are both healthcare related: Dr Beverly Crusher, the Chief Medical Officer and Deanna Troi, the ship's therapist. This shift from ST:TOS, where the most senior female was iconic communication officer Nyota Uhura, is significant and reflects more general debates which featured in the 1980s media concerning gender equality. These characters clearly represent some sort of progress regarding positive depictions of women in primetime television. However, as with Fraiser and Russell, both mainly reproduce traits (culturally constructed) which tend to be attached to women in fictional media. ${ }^{24}$ They possess skills associated with a constructed 'femininity' such as, sensitivity, perception and intuition. Both are at times preoccupied with concerns about their personal lives. ${ }^{25}$ Thus Deanna Troi is an extreme example of this constructed 'femininity' with 'female' medical abilitiesshe is a half-human, half-Betazoid empath who can telepathically read emotions and judge whether an individual is attempting deception or subterfuge.

At a time when debates were circulating concerning gender equality, Dr Crusher's character appeared to be designed as the fantasy woman. She is the most senior female officer in the Enterprise crew, leads a medical team and is a close confidante of the Captain. Crusher is also a single mother who occasionally also takes command of the starship. Crusher exhibits an extraordinary competence that borders on infallibility. 'She is in all respects a superwoman'. ${ }^{26}$ Like McCoy before, Crusher's character has had an undoubted positive influence with material consequences beyond the show. One female medical student recalled 'I think Dr Crusher had a real impact on my formative years-a woman physician who was strong, smart, and respected, who the guys went to when they didn't have the answers' 27

The role of female physician also provides opportunities to explore the ways in which science fiction television facilitates disruptions along the lines of gender and sexuality that would appear to challenge the heteronormativity of television drama and the media of the time. The ability for science fiction to offer provocative possibilities concerning sexuality and female power is coupled with the potential to disrupt traditional assumptions concerning gender, sexuality and bodies. However, such depictions are often limited by the prevailing sociocultural mores. In a ground-breaking episode which explores the complexities of sexuality, Crusher falls in love with a Trill ambassador, Odan ('The Host', ST:TNG). The Trill are a symbiotic species with the ability to bond with host bodies. After Odan is fatally injured he temporarily transfers his identity to a male Starfleet officer's body, William T Riker. Crusher is a close friend of Riker and initially struggles with this transition but eventually continues a sexual relationship. The ethical consequences of Riker providing a body, used for sexual purposes by his close colleague, were only hinted at in the narrative. However, when a woman arrives as Odan's permanent host, 
Crusher rejects her saying 'perhaps it is a human failing; but we are not accustomed to these kinds of changes'. This exploration of transgender issues and ultimate rejection by Crusher on the grounds of universalism drew mixed responses from "Gaylaxians' ${ }^{\text {,iv }}$ who felt the episode embodied the ideological limitations of the show. It seems to imply that sexual relations with someone as they go through a gender transition are impossible, even in the 23 rd century. ${ }^{28}$

\section{Beyond human: identity, difference and diversity}

Discussions concerning the fluid and unstable nature of identity were often reflected in the representations of doctors in science fiction that followed, with gender and sexuality being common themes. In particular, debates about intersectionality opened up the possibilities of subject positions being multiple and relational. ${ }^{29}$ For example, Doctor Phlox from 'Star Trek: Enterprise' (ST:ENT 2001-2005) is the alien (Denobulan) Chief Medical Officer on Enterprise-he is part of an 'Interspecies Medical Exchange'. As well as being a fully trained Doctor he holds six degrees in interspecies veterinary medicine and is an advocate of a species-spanning approach to healthcare. He maintains a menagerie of plants and animals in the sick bay which he uses to prepare therapies to complement his traditional pharmaceuticals. Hence, as a multicultural physician of the future he is relaxed with technology and is able to draw on alternative healing methods-'Dr. Phlox reflects the swelling backlash against failed technologies that presently lead so many to experiment with non-traditional or "natural" remedies". ${ }^{26}$

In this prequel to ST:TOS his attitudes are contrasted with those of his fellow crew members and he maintains an open and positive stance on diversity (species and cultures). In 'A Night in Sickbay' (ST:ENT), the primary focus is on Captain Archer's companion animal, a dog named 'Porthos', who has been severely taken ill. But a subplot involves increasing tensions between Captain Archer and his female Vulcan First Officer, T'Pol. During a long night with Archer and the doctor together in sickbay, Phlox suggests that this conflict may be due to sexual tension:

for the past few months I've noticed increasing friction between you and the sub-commander, you must understand that I am trained to observe these things... when one person believes their sexual attraction toward another is inappropriate, they often exhibit unexpected behaviour (ST: ENT)

During a delicate procedure to transplant a pituitary gland from a Calrissian chameleon into Porthos, Archer asks Phlox whether his expertise on sexual matters was based on professional or personal experience. Phlox explains that he has two wives, who in turn each have two other husbands beside himself. His family unit consists of a total of 720 possible relationships, 42 of which have romantic possibilities, and 31 children (Archer 'sounds very complicated', Phlox 'Very. Why else be polygamous'). The character of Phlox thus represents a complex and fluid chain of equivalences. ${ }^{30}$ His own sociotechnical background and non-species specific training, his use of alternative and traditional therapies and his non-monogamous group relationship and polyamory all represent floating signifiers which ascribe a diverse fluidity to his subject position. But his status as an 'alien outsider', visually marked as different, on board the Enterprise means this estrangement is narratively present, but effectively neutralised.

\footnotetext{
${ }^{\text {iv } G a y, ~ l e s b i a n, ~ b i s e x u a l ~ a n d ~ t r a n s g e n d e r ~ f a n s ~ o f ~ S t a r ~ T r e k . ~}$
}

The 'doctor as different' is a theme also explored with the representations of two other Star Trek physicians: Dr Julian Bashir on 'Star Trek: Deep Space Nine' (ST:DS9 1993-1999) and the artificial intelligence (AI) doctor known simply as the 'Emergency Medical Hologram' (EMH) on 'Star Trek: Voyager' (ST:VOY 1995-2001). In ST:DS9 issues concerning the psychosocial implications of genetic engineering and enhancement are examined. We discover that Dr Bashir has been genetically engineered as a young boy because he had learning difficulties. Thus Bashir embodies the mentally superior and physically enhanced doctor that is in some respects posthuman (simultaneously using and also being a product himself of genetic modification technology). Within the Star Trek United Federation of Planets, human genetic engineering is illegal, and Bashir has kept his abilities secret throughout most of his adult life. Thus Bashir has to make deliberate 'humanlike' mistakes occasionally to conceal his true identity. ${ }^{\mathrm{v}}$ This is taken to extremes in ST:VOY where the AI doctor is 'made human' by sophisticated software and holographic routines which gives him a male form. In addition to the satirical opportunities that the AI doctor affords (eg, expressing unhappiness with his working conditions and an AI arrogance) he also reverberates with the changing medical environment of the period reflecting the increasing use and reliance upon 'intelligent medical devices' and debates that speak to the deskilling of medical practice. A constant theme throughout the series franchise, continued here, concerns what it means to be human. Again we can see an estrangement within the narrative discourse as the AI doctor challenges and disrupts the taken-for-granted assumptions that humans are morally superior. This is brought into focus when the EMH discovers he has been denied access to his own memory files on the orders of Captain Janeway. It emerges that the EMH has developed a dangerous feedback loop between his cognitive and ethical subroutines caused by an internal cognitive conflict where he chooses to save a friend rather than another member of the crew. Portions of his memory are removed in order to rectify the perilous 'logic loop'.

It is the artificial non-organic EMH who challenges the actions of Janeway as unethical, reminding her that despite being a 'machine' he can still feel 'violated':

EMH: How would you like it if I operated on you without your consent or without your knowledge?

JANEWAY: If the operation saved my life? I could live with it. EMH: I don't believe you. You'd feel as violated as I do right now (ST:VOY 'Latent Image').

Thus this character is able to provoke reflection on what it means to be human, the nature of individuality and to what extent the crew are willing to cross ethical boundaries to ensure the preservation of their artificial crew member. The EMH emulates human characteristics, yet he is treated like a machine when his programming causes him to feel unresolvable 'guilt'.

\footnotetext{
vThese anxieties about genetic engineering trace back directly to ST:TOS where the character Khan Noonien Singh is introduced (ST:TOS 'Space Seed'). Khan is the 'supervillain' leader of a group of 20th century genetically enhanced 'superhumans'. Rather than enhancing humanity they are depicted as flawed, becoming warlords and sparking the Eugenics Wars, Earth's last major global conflict. A pejorative reference to a posthuman future is explicitly mentioned when one of this group refers to Nietzsche's Übermensch, asserting 'Mankind is something to be surpassed' (ST:ENT 'Borderland').
} 
Universality of health care and the aliens amongst us: 'all of this has happened before, and it will happen again...'vi

The moral and ethical role of the physician at the heart of these futuristic programmes appears remarkably stable. The various Trek outings share a set of positive characteristics about the future of healthcare including equality of care and an altruistic concern for the welfare of patients regardless of race or species (indeed the Starfleet Federation have an explicit policy of not restricting access to its medical supplies, ST:TNG 'The Mind's Eye'). Yet, the delivery of medical care is consistently represented as taking place within a quasi-military context, although one that is dedicated to exploration. Nevertheless, the Star Trek series consistently represents a utopian Federation, a vision of the evolution of an idealised United Nations that shares some characteristics with the utopian 'Culture' of Iain M Banks's novels. In contrast, the reimagining of Battlestar Galactica (BSG, 2003-2009) introduces a far bleaker, more complex vision of the moral uncertainties of a 'post 9/11' world.

The reinvented $B S G$ captured a public anxiety concerning the role of the USA as 'moral leader' in the war on terror. The series poses complex moral dilemmas and critiques human capacity for violence. Overarching storylines concern the elements of democracy which can be sacrificed in the struggle to win a war. Ethics are shown to be in a constant state of flux. Here the powerful 'enemy within' is the Cylon race-synthetic humans evolved from androids created to serve as slaves. These Cylons are sentient enemies that look human and share our biology but are focused on annihilating the human race. This plays on fears of terrorist infiltration and anxieties about the alien 'Other'. ${ }^{31}$ In BSG, the doctor, Chief Medical Officer Major Sherman Cottle, is firmly embedded in a military State where national security is in constant jeopardy, civilians are under martial law, and many of his colleagues are experiencing burnout and paranoia. Dr Cottle displays a healthy disdain for authority and is almost always seen smoking a cigarette, even during patient consultations.

The show raises important questions concerning biopolitics, race, gender and torture. ${ }^{32-35}$ Here Dr Cottle embodies the considerable pressures faced by medics in combat zones. His medical role, and the relative autonomy it allows him serves to accelerate the plot at crucial points in the story arc, not least faking the death of a hybrid human-Cylon infant to protect the child (BSG 'Downloaded'). Like previous science fiction doctors, Cottle is often the moral centre point of an ethically ambiguous universe. He upholds the Hippocratic Oath in treating Cylons and humans equally, actively disapproving of the grave sexual assault of Cylon prisoner 'Sharron' which challenges his colleagues' view that 'a machine can't be raped' (BSG 'Resurrection Ship'). Indeed issues of the precarious position of rights over reproduction and body politics within war are a strong recurring theme in the series. ${ }^{33}$ Where fear of overpopulation is evident in Star Trek, ${ }^{5}$ the converse is the case in BSG where there are just 50000 human souls left prompting the traditionally liberal President Roslin to criminalise abortion. It emerges that Cottle has long been performing abortions on request 'without asking a lot of questions' (BSG 'The Captain's Hand'). Cottle also disagrees ethically with the use of alien blood to treat the dying President Roslin's breast cancer, saying 'I don't like what you're doing, I think it's unnatural and damn dangerous... maybe it's just her time' (BSG 'Epiphanies'). The doctor here simultaneously expresses fears about the dangers of both tampering with nature and of the hybridisation that might result from mixing human and alien blood. There are obvious references here to the Frankenstein frame, the 'governing myth' for debates about life creation and biotechnology for over two centuries. $^{36}$

Doctor Cottle's administration of medicine and healthcare can, therefore, be seen as signifying an ethical resistance to the all-encompassing needs of the military in times of waralthough a resistance that is largely ineffectual. This contrasts strongly with the universe of ST:TNG where Deanna Troi's empathic abilities are frequently used by Captain Picard to uncover hidden motivations of potential enemies and also members of his own crew-to literally get inside the minds of friends and foes alike. Issues of surveillance and privacy and the ethical repercussions of using Troi's psychological powers in this way are simply not featured as ethically problematic in these earlier series yet in our post 9/11 era the militarisation of psychology is an issue of considerable debate. ${ }^{37}$

\section{CONCLUSION}

We might argue that doctors in space (ships) perform essential narrative articulations in an attempt to establish hegemonic formations. Indeed, they function as an ethical point of narrative stability-they effectively became a collective moral 'glue' in the communities they inhabit. ${ }^{\text {vii }}$ Despite the depiction of the advanced medical 'gadgets' available to these futuristic medics, the role of the doctor continues to be the reassuring figure of a family physician, the general practitioner who is firmly embedded in their community and who performs a task of delivering healthcare and can act as confidante and advisor. McCoy speaks to a nostalgia for this fantasy physician, at ease with the technoscience of the future but capable of understanding the human condition and the psychosocial 'fall out' we experience when facing ill health. McCoy represents the doctor we would all want to have at our bedside and (re)appeared at a time of increasing concerns about the funding of healthcare. His nostalgic presence functions to stabilise the potential narrative disruptions brought about by futuristic technoscience and 'gadgets'. We can see this too with Dr Crusher whose very presence reflected wider critiques concerning professional women in television (and medicine) and who carries the significant burden of representing multiple idealised identities (parent, physician and flawless professional). Yet she cannot step far beyond her ideological narrative constraints when it comes to issues of alternative sexualities.

The setting of science fiction television in a utopian or dystopian future always refracts and focuses concerns about our present-it 'makes manifest our collective anxieties, transforming and projecting them onto monstrous and alien bodies'. ${ }^{39}$ The figure of the doctor represents different tensions about the delivery of posthuman healthcare: the genetically enhanced human, the alien physician and the AI non-human professional. 'Difference' is signified either visually (Phlox the alien) or referenced internally (part human hybrid Bashir, non-organic $\mathrm{EMH})$. But this difference, in turn, is part of a discursive stabilisation of the narrative. For example, if it were human members of the Starfleet crew that were widely engaged in polyamorous activity as the norm, then this would challenge our social definitions of appropriate sexual behaviour. The alternative sexualities

vii The encounters between doctor and patient in 'A Fortunate Man' reflect this relationship very powerfully. It has been described as 'the most important book about general practice ever written'. ${ }^{38}$ 
and lifestyles of Phlox are permissible because he does not resemble his viewers and thus can be neatly 'othered'.

Dr Cottle represents a different posthuman future-an apocalyptic one where humans may cease to exist at all. As well as symbolising concerns about the future of humanity, he also presents us with a discourse of hope, an idealised (possibly unrealistic) view of the tensions that the caring health sciences must navigate in a world engaged in a 'war on terror'. At the time of writing, it is being reported that we may be on the brink of a new period of both local and global insecurity. The delivery of healthcare is still in flux with debates continuing concerning funding, rationing and the threat to human identity through novel technologies. How this might influence and reflect the doctors that will be presented to future sci-fi audiences remains in question, but the science fiction doctor facilitates the personalisation of technological change, a useful conduit through which public anxieties concerning health, bioethics and morality are expressed and explored.

Twitter Follow Lesley Henderson at @lesleyhenders

Contributors $\mathrm{LH}$ and SC both contributed to the research and writing of this paper. LH conceptualised the study, analysed the visual material and drew on her research in health and science in television fiction to provide insights from cultural and media studies. SC helped conceptualise the study, analysed the visual material and provided insights from Medical Sociology and Science and Technology Studies.

Competing interests None declared.

Provenance and peer review Not commissioned; externally peer reviewed.

Data sharing statement The programme episodes are all available publicly and additional information on analysis can be provided by writing to the authors.

Open Access This is an Open Access article distributed in accordance with the Creative Commons Attribution Non Commercial (CC BY-NC 4.0) license, which permits others to distribute, remix, adapt, build upon this work non-commercially, and license their derivative works on different terms, provided the original work is properly cited and the use is non-commercial. See: http://creativecommons.org/ licenses/by-nc/4.0/

\section{REFERENCES}

1 AMA President Robert Wah proudly claims his 'Star Trek' roots. Modern Healthcare, 21 Jun 2014. http://www.modernhealthcare.com/article/20140621/MAGAZINE/ 306219956 (accessed 15 Aug 2016)

2 Casarett D, Fishman JM, MacMoran HJ, et al. Epidemiology and prognosis of coma in daytime television dramas. BMJ 2005:331:1537-9.

3 Jacobs J. Body trauma TV: the new hospital dramas. London: BFI, 2003.

4 Turow J. Television entertainment and the US health-care debate. Lancet 1996;347:1240-3.

5 Grech V. Infertility in Star Trek. World Future Rev 2012;4:19.

6 Stratmann H. Using medicine in science fiction. New York, NY: Springer International Pub., 2016.

7 Michael M, Carter S. The Facts about Fictions and Vice Versa: Public Understanding of Human Genetics. Sci Cult 2001;10:5-32.

8 Karpf A. Doctoring the media: the reporting of health and medicine. Routledge, 1988.

9 Hall S. The rediscovery of 'ideology': return of the repressed in media studies. In: Beechey V, Donald J, eds. Subjectivity and social relations. Milton Keynes: Open University Press, 1985:2-23.

10 Orwell G. Collected essays, journalism and letters. Harmondsworth: Penguin, 1970.
11 Suvin D. Metamorphoses of science fiction: on the poetics and history of a literary genre. New Haven and London: Yale University Press, 1979.

12 Wagner JG, Lundeen J. Deep space and sacred time: Star trek in the American mythos. Westport, CT: Praeger, 1998.

13 Whitfield SE, Roddenberry G. The making of Star trek. New York: Ballantine Books, 1968.

14 Cosgrove BW. Eugene Smith's Landmark Portrait: 'Country Doctor'. Time, 1 Feb 2012. http://time.com/3456085/w-eugene-smiths-landmark-photo-essay-countrydoctor/ (accessed 15 Aug 2016).

15 Willumson GG, Smith WE. W. Eugene Smith and the photographic essay. Cambridge, UK; New York, NY, USA: Cambridge University Press, 1992

16 Henderson L. Medical TV dramas: health care as soap opera. In: Panitch L, Leys C, eds. Morbid symptoms: health under capitalism. London: Merlin Press, 2010:198-215.

17 Vandekieft G. From City Hospital to ER: the evolution of the television physician. In: Friedman L, ed. Cultural sutures: medicine and media. London: Duke University, 2004:218.

18 Ehrenreich B, Ehrenreich J. The American health empire: power, profits, and politics. A Health-PAC book. Prepared by Barbara \& John Ehrenreich. New York: Vintage Books, 1971.

19 Freidson E. Profession of medicine. A study of the sociology of applied knowledge. New York: Dodd, 1988.

20 Illich I. Medical nemesis: the expropriation of health. London: Calder and Boyars, 1975.

21 Kennedy I. The unmasking of medicine. London: Allen \& Unwin, 1981.

22 Karpf A. Doctoring the media : the reporting of health and medicine. Ghfu: Routledge, 1988:188.

23 Tuchman G, Daniels AK, Benét JW. Hearth and home: images of women in the mass media. New York: Oxford University, 1978.

24 Henderson L. Social issues in television fiction. Edinburgh: Edinburgh University Press, 2007.

25 Brunsdon C. The feminist, the housewife, and the soap opera. New York: Clarendon Press, 2000

26 Petrany SM. Star Trek and the future of family medicine. Fam Med 2008;40:132-3.

27 Pomidor B, Pomidor A. Essay: "With great power..." The relevance of science fiction to the practice and progress of medicine. Lancet 2006;368:S13-14.

28 Tulloch J, Jenkins H. Science fiction audiences: watching Doctor Who and Star Trek. London: Routledge, 1995.

29 Phoenix A, Pattynama P. Intersectionality. Eur J Womens Stud 2006;13:187-92.

30 Laclau E, Mouffe C. Hegemony and socialist strategy: towards a radical democratic politics. London: Verso, 1985

31 Koistinen A-K. Passing for human in science fiction: comparing the TV Series Battlestar Galactica and V. NORA Nordic J Womens Stud 2011;19:249-63.

32 Dies C. Erasing difference: the Cylons as racial other. In: Potter T, Marshall W, eds. Cylons in America: critical studies in Battlestar Galactica. New York: Continuum, 2008:156-68.

33 Hellstrand I. The shape of things to come? Politics of reproduction in the contemporary science fiction series "Battlestar Galatica". NORA Nordic J Womens Stud 2011;19:6-24.

34 Johnson-Lewis E. Torture, terrorism, and other of human nature. In: Potter T, Marshall W, eds. Cylons in America: critical studies in Battlestar Galactica. New York: Continuum, 2010:27-39.

35 Leaver T. 'Humanity's children': constructing and confronting the Cylons. In: Potter T, Marshall W, eds. Cylons in America: critical studies in Battlestar Galactica. New York: Continuum, 2008:27-39.

36 Turney J. Frankenstein's footsteps: science, genetics and popular culture. New Haven; London: Yale University Press, 1998.

37 Pope KS, Gutheil TG. Psychologists abandon the Nuremberg ethic: concerns for detainee interrogations. Int J Law Psychiatry 2009:32:161-6.

38 Felder G. A Fortunate Man: still the most important book about general practice ever written. Br J Gen Pract 2005;55:246-7.

39 Nishime L. Aliens: narrating U.S. global identity through transnational adoption and interracial marriage in Battlestar Galactica. Crit Stud Media Commun 2011;28:450. 